\title{
PELAKSANAAN PEMENUHAN HAK ATAS PELAYANAN KESEHATAN BAGI PEREMPUAN NARAPIDANA DALAM KEADAAN HAMIL (Studi Kasus Lembaga Pemasyarakatan Perempuan Kelas IIB Yogyakarta)
}

\author{
Aggreini Kresnadari \\ Email : anggreini_kresnadari@yahoo.com \\ Mahasiswa Program Magister Ilmu Hukum Program Pascasarjana \\ Fakultas Hukum Universitas Sebelas Maret Surakarta \\ Isharyanto \\ Email : isharyantoisharyanto8@gmail.com \\ Supanto \\ Email : supanto07@yahoo.com \\ Dosen Fakultas Hukum Universitas Sebelas Maret Surakarta
}

\begin{abstract}
This article examines the implementation of the fulfillment of the right to health services for woman prisoners in a state of pregnancy (case study of women's class IIB Yogyakarta). This research is legal (judicial) normative, namely by reviewing library materials (literature study). Therefore, the data used in this research is secondary data, which includes the pimary legal materials,secondary, and tertiary. The results of this study indicate that every pregnant female prisoners is fulfilled her right to obtain health service in class IIB Yogyakarta of Goverment regulation number 32 year 1999 due to the existence of monitoring and evaluation by head of womens's prisoners class IIB Yogyakarta in order to minimize any barriers that occur in the implementation of the fulfillment of the right to health services for woman who are pregnant.

Keywords : implementation of the fulfillment of rights; female prisoners; health services
\end{abstract}

\begin{abstract}
Abstrak
Artikel ini mengkaji tentang pelaksanaan pemenuhan hak atas pelayanan kesehatan bagi perempuan narapidana dalam keadaan hamil (studi kasus Lembaga Pemasyarakatan Perempuan Kelas IIB Yogyakarta). Penelitian ini merupakan penelitian hukum (yuridis) normatif, yaitu dengan mengkaji bahan-bahan pustaka ( studi kepustakaan). Karena itu, data yang digunakan dalam penelitian ini adalah data sekunder, yang mencakup bahan hukum primer, sekunder, dan tersier. Hasil penelitian ini menunjukkan bahwa setiap narapidana perempuan yang sedang hamil dipenuhi haknya untuk memperoleh pelayanan Kesehatan di Lembaga Pemasyarakatan Perempuan Kelas IIB Yogyakarta sesuai dengan pasal 20 ayat (1) Peraturan Pemerintah Nomor 32 Tahun 1999. Karena adanya monitoring dan evaluasi oleh Kepala Lembaga Pemasyarakatan Perempuan Kelas IIB Yogyakarta sehingga dapat meminimalisir segala hambatan yang terjadi dalam pelaksanaan pemenuhan hak atas pelayanan kesehatan bagi perempuan yang sedang hamil.
\end{abstract}

Kata kunci : pelaksanaan pemenuhan hak; narapidana perempuan; pelayanan kesehatan 


\section{A. Pendahuluan}

Narapidana sesuai pasal 1 angka 7 Undang-undang No 12 Tahun 1995 adalah terpidana yang menjalani pidana hilang kemerdekaan di Lembaga Pemasyarakatan (LAPAS). Pengakuan hak-hak narapidana, termasuk perempuan narapidana terlihat pada materi muatan yang terkandung dalam pasal 14 Undang-Undang No 12 Tahun 1995 tentang Pemasyarakatan.

Dalam hal pemenuhan hak bagi narapidana ini terselipkan salah satu hak yang sangat krusial dan harus terpenuhi yaitu hak mendapatkan pelayanan kesehatan dan makanan yang layak. Narapidana wanita tentu berbeda dengan narapidana pria, karena narapidana wanita mempunyai keistimewaan yang tentu tidak dimiliki oleh narapidana pria seperti siklus menstruasi, hamil, melahirkan, menyusui. Sehingga kebutuhan wanita lebih spesifik terutama dalam hal pelayanan kesehatan khususnya untuk wanita yang sedang hamil sampai melahirkan dan menyusui. Apabila narapidana wanita yang sedang hamil menjalankan proses pembinaan di LAPAS ini mempunyai hak yang lebih spesifik dan urgensinya lebih mendalam selama masa kehamilannya.

Tahanan perempuan menjadi objek yang paling dekat dengan kerentanan tersebut. Fasilitas keruangan yang menunjang aktivitas perempuan tak terlengkapi. Ini menjadi salah stu indikator kurang terpenuhinya hak-hak perempuan. Hasil pemantauan Komnas Perempuan terhadap kondisi tahanan perempuann di Naangroe Aceh Darussalam (NAD) pada tahun2006 memperkuat persepsi tersebut. Dari 65 tahanan perempuan di NAD, Komnas Perempuan menyimpulkan bahwa pihak atau lembaga yang menahan telah mengabaikan kebutuhan spesifik perempuan. Mulai kondisi ruangan, penerangan, ketersediaan air bersih, sampai layanan kesehatan reproduksi. Kondisi ini tidak hanya dialami oleh tahanan perempuan yang disekap di pos-pos militer, tetapi juga terjadi di rutan atau Lapas yang notabenenya lembaga resmi penahanan. Dibedakan di Indonesia, tak ada perlakuan atau penambahan hak khusus terhadap tahanan perempuan. Mereka diperlakukan seperti umumnya tahanan laki-laki. Padahal, perempuan yang tingkat 
kekebalan tubuhnya tidak sekuat laki-laki seharusnya mendapat fasilitas akomodatif di ruang tahanan, bahkan dalam hal pelayanan medis (Musyafak Timur). Lebih memprihatinkan, menurut pemantauan Komnas Perempuan, aparat pelaku penahanan tidak menjalankan kewajiban melindungi tahanan perempuan. Bahkan, Komnas Perempuan menemukan kasus-kasus kekerasan terhadap tahanan perempuan yang justru dilakukan aparat pelaku penahanan.

Manfred Nowak, pengacara HAM sekaligus pelapor khusus Perserikatan BangsaBangsa (PBB) bidang penyiksaan dan perlakuan tidak manusiawi, melaporkan adanya perlakuan tak wajar di penjara-penjara di Indonesia. Penjara di Indonesia, seperti laporan Nowak masuk dalam daftar "horror" PBB. Menurutnya, tahanan di Indonesia kurang mendapatkan makanan dan obat-obatan. Bahkan, tahanan dipaksa membayar uang harian untuk akomodasi yang diterima selama di penjara. Semasa menjalani masa hukuman, tahanan perempuan rawan sekali tertimpa pelecehan seksual. Untuk mengantisipasi hal itu, aparat penahan di Lapas atau Rutan perempuan harus didominasi oleh perempuan. Peluang untuk melakukan tindak kekerasan maupun pelecehan seksual di Rutan atau Lapas perempuan menjadi sempit jika aparat yang bertugas menjaga dan membina adalah perempuan.

Hak asasi manusia (HAM) merupakan masalah dunia internasional bukan hanya masalah internal dari suatu negara (wolfgang, 1964:3). HAM adalah hak-hak manusia. Itulah hak-hak semua manusia yang sepenuhnya setara. Semua hak itu berasal dari martabat inheren manusia dan telah didefinisikan sebagai klaim-klaim manusia, untuk diri mereka sendiri atau untuk orang lain yang didukung oleh suatu teori yang berpusat pada perikemanusiaan manusia, pada manusia sebagai manusia, dan anggota umat manusia (Komisi Hak Asasi Manusia, 1996 : 56).

Pada Sidang Majelis Umum tanggal 10 Desember 1948, PBB mendeklarasikan pernyataan umum hak asasi manusia melalui Universal Declaration Independent of Human Rights (Deklarasi Universal Hak Asasi Manusia/DUHAM). DUHAM ini berisi 30 pasal. Semua pasal tersebut menegaskan pada semua bangsa bahwa setiap manusia dilahirkan itu memiliki hak fundamental yang tidak dapat dirampas dan dicabut oleh manusia lainnya (Bonita, 2004: 23). 
Kesehatan pribadi, baik fisik maupun mental merupakan prasyarat penting bagi tercapainya kesejahteraan maupun derajat tertinggi dari kehidupan manusia. Atas dasar pertimbangan tersebut maka hak untuk mendapatkan standar kesehatan yang paling tinggi dirumuskan sebagai suatu hak asasi.

Terkait dengan pemenuhan hak atas kesehatan, di dalam pasal 25 ayat (1) DUHAM dinyatakan bahwa setiap orang berhak atas taraf hidup yang memadai untuk kesehatan dan kesejahteraan dirinya dan keluarganya, termasuk hak atas pangan, pakaian, perumahan dan perawatan kesehatan serta pelayanan sosial yang diperlukan, serta hak atas keamanan pada saat menganggur, sakit, cacat, menjadi janda, usia lanjut, atau keadaan-keadaan lain yang mengakibatkannya kekurangan penghasilan, yang berada di luar kekuasaannya (pasal 25 ayat 1 DUHAM). Narapidana wanitasebagai manusia juga memiliki hak atas kesehatan sebagaimana dijamin dalam pasal 25 Ayat (1) DUHAM tersebut.

Dalam Pasal 11 ayat (1) huruf f Convention on The Elimination of All Forms of Dicrimination Against Women (Konvensi mengenai Penghapusan Segala Bentuk Diskriminasi terhadap Wanita/CEDAW) sebagaimana telah diratifikasi oleh Indonesia dengan Undang-Undang Nomor 7 Tahun 1984 salah satunya dicantumkan bahwa perempuan mempunyai hak atas perlindungan kesehatan. Dikarenakan konvensi internasional ini telah diratifikasi oleh Indonesia dan mengikat maka negara untuk wajib mengakui hak dan melaksanakan perlindungan terhadap wanita sebagaimana diatur dalam Konvensi dan terikat pada sistem pemantauan dan pelaporan internasional. Negara wajib memenuhi perlindungan atas hak kesehatan wanita.

Gagasan merumuskan perlindungan hak-hak minimal untuk orang- orang yang direnggut kebebasannya oleh putusan pengadilan sudah mulai dirintis pada pertemuan internasional Komisi Hukum Pidana dan Kepenjaraan di Bern, Swiss, tahun 1926. Sampai akhirnya bermuara kepada terformulasinya berbagai instrumen dalam bentuk non-binding instrumen tersebut $\mathrm{di}$ atas. Sebagai instrumen internasional yang diformulasikan dalam bentuk standard minimum rules atau basic principles maka instrumen-instrumen itu not directly binding,yang tidak dapat dipaksakan pemberlakuannya seperti treaty. Instrumen ini hanya bersifat quasi legal standard yang 
pengintegrasiaannya ke dalam legislasi nasional setiap negara sangat tergantung pada kemauan negara itu sendiri.

Dalam Standard Minimum Rules United Nations for The Treatment of Prisoner, 31 juli 1957, dinyatakan bahwa instalasi saniter hak-hak narapidana dalam hal ini narapidana wanita yang hilang kemerdekaannya karena melakukan tindak pidana, haruslah dilakukan sesuai dengan HAM.

Menurut Undang-Undang Nomor 12 Tahun 1995 tentang Pemasyarakatan Pasal 1 angka 1 yang dimaksud dengan pemasyarakatan adalah kegiatan untuk melakukan pembinaan warga binaan pemasyarakatan berdasarkan sistem kelembagaan yang merupakan bagian akhir dari sistem pemidanaan dalam tata peradilan pidana. Sistem pemasyarakatan merupakan suatu sistem perlakuan terhadap narapidana yang menganut konsep pembaharuan pidana penjara yang berdasarkan Pancasila dan asas kemanusiaan yang bersifat universal. Sistem ini menganut sistem mengintegrasikan narapidana ke dalam masyarakat melalui program-program pembinaan yang lebih memperhatikan hak-hak narapidana dibandingkan dengan sistem yang lama yaitu sitem kepenjaraan.

Pengakuan hak-hak narapidana terlihat pada materi muatan yang terkandung dalam pasal 14 Undang-Undang Nomor 12 tahun 1995 tetang Pemasyarakatan, bahwa narapidana berhak mendapatkan pelayanan kesehatan dan makanan yang layak. Selanjutnya dirinci lagi dalam Peraturan Pemerintah Nomor 32 Tahun 1999 tentang syarat dan Tata Cara pelaksanaan Hak Warga Binaan Pemasyarakatan, pasal 14 dan pasal 20 ayat (1) bagian ke empat mengenai pelayanan kesehatan dan makanan dinyatakan bahwa :

Pasal 20 ayat (1)

(1) Narapidana dan anak didik pemasyarakatan yang sakit, hamil atau menyusui berhak mendapatkan makanan tambahan sesuai degan petunjuk dokter.

Dalam penjelasan pasal tersebut dinyatakan bahwa yang dimaksud dengan makanan tambahan adalah penambahan jumlah kalori di atas rata-rata jumlah kalori yang ditetapkan. Bagi wanita yang sedang hamil ditambah 300 (tiga ratus) kalori seorang sehari. Bagi wanita yang sedang menyusui dapat ditambah antara 800(delapan ratus) sampai dengan 1000 (seribu) kalori seorang sehari. 
Di dalam pasal pasal 20 ayat (3) Peraturan Pemerintah tersebut dinyatakan bahwa anak dari narapidana wanita yang dibawa ke dalam lembaga pemasyarakatan atau pun yang lahir di lembaga pemasyarakatan dapat diberi makanan tambahan atas petunjuk dokter, paling lama sampai anak berumur 2 (dua) tahun. Maksud dari pemberian makanan tambahan tersebut diungkapkan di dalam penjelasan Pasal 20 Ayat (3) yaitu bahwa pemerian makanan tambahan dimaksudkan untuk menjaga terpeliharanya pertumbuhan dan perkembangan anak.

Narapidana wanita tentunya berbeda dengan narapidana pria, dimana narapidana wanita mempunyai keistimewaan khusus yang tidak dimiliki oleh narapidana pria yaitu narapidana wanita mempunyai siklus seperti menstruasi, hamil, melahirkan dan menyusui. Kebutuhan spesifik perempuan ini seperti pemulihan kesehatan reproduksi, keluarga berencana, pelayanan untuk kehamilan serta masa melahirkan, dan perawatan setelah mengalami kekerasan atau penyiksaan seksual. Hak-hak narapidana wanita yang berhubungan dengan hal-hal tersebut sudah selayaknya dipenuhi dan diperhatikan.

Narapidana wanita menghadirkan tantangan tertentu bagi pihak yang berwenang atas Lapas, lantaran, atau mungkin karena mereka merupakan kelompok yang sangat kecil dalam populasi Lapas. Profil dan latar belakang perempuan dalam Lapas dan alasan mengapa mereka dipenjarakan berbeda dari narapidana laki-laki yang berada dalam situasi yang sama. Empat pengguna narkoba suntik dan pekerja seks, pada khususnya, lebih banyak jumlahnya. Sekali mereka berada dalam Lapas, kebutuhan psikologis, kebutuhan perawatan dan kesehatan dan kebutuhan sosial mereka juga akan berbeda. Akibatnya, seluruh fasilitas, program, dan pelayanan Lapas harus disesuaikan untukmemenuhi kebutuhan khusus pelaku pelanggaran perempuan (Andrew, 2002).

Menurut hasil prasurvey di Lembaga Pemasyarakatan Perempuan Kelas IIB Yogyakarta bahwa LAPAS dihuni oleh 88 orang dan 1 orang diantaranya sedang hamil. Sehubungan dengan pemenuhan hak memperoleh pelayanan kesehatan bagi narapidana wanita yang sedang hamil di Lembaga Pemasyarakatan Perempuan Kelas IIB Yogyakarta, maka diperlukan konstribusi secara langsung terhadap baik bagi narapidana wanita yang sedang hamil itu sendiri, para petugas pemasyarakatan dan pihak-pihak lain yang bersangkutan. 
Berdasarkan latar belakang tersebut, maka artikel ini mengkaji bagaimana pelaksanaan pemenuhan hak atas pelayanan kesehatan bagi perempuan narapidana dalam keadaan hamil di Lembaga Pemasyarakatan Perempuan Kelas IIB Yogyakarta.

\section{B. Metode Penelitian}

Jenis penelitian adalah penelitian hukum. Hal ini berdasarkan pendapat Peter Mahmud Marzuki bahwa tidak perlu istilah penelitian hukum normatif, karena legal research atau bahasa Belanda rechtsonderzoek selalu normatif. Sama halnya dengan istilah yuridis normatif yang sebenarnya tidak dikenal dalam penelitian hukum (Peter ,2014 :55-56). Penelitian yang dikaji penulis dalam penelitian ini merupakan penelitian yang bersifat preskriptif, yang dimaksudkan untuk memberikan argumentasi atas hasil penelitian yang telah dilakukan.

Pendekatan yang digunakan peneliti dalam penulisan hukum ini adalah pendekatan undang-undang (statute approach), dan pendekatan konseptual (conceptual approach). Bahan hukum primer. Bahan hukum primer merupakan bahan hukum yang bersifat autoritatif artinya mempunyai otoritas. Bahan-bahan hukum primer terdiri dari perundang-undangan, catatan-catatan resmi atau risalah dalam pembuatan perundangundangan dan putusan-putusan hakim. Adapun yang menjadi bahan hukum primer dalam penelitian ini adalah: Undang-Undang Dasar Negara Republik Indonesia Tahun 1945, Universal Declaration of Human Rights (DUHAM), Convention on The Elimination of All Forms of Dicrimination Againts Women (CEDAW), Kovenan Internasional Hak-Hak Sipil dan Politik, Undang-undang nomor 12 Tahun 1995 tentang Pemasyarakatan, Undang-undang Nomor 39 Tahun 1999 tentang Hak Asasi Manusia, Undang-undang Nomor 36 tahun 2009 tentang Kesehatan, Peraturan Pemerintah Nomor 32 tahun 1999 tentang syarat dan tata cara Pelaksanaan Hak Warga Binaan Pemasyarakatan. Bahan hukum sekunder, bahan hukum sekunder yang utama adalah buku teks karena buku teks berisi mengenai prinsip-prinsip dasar ilmu hukum dan pandangan-pandanga klasik para sarjana yang mempunyai kualifikasi tinggi. Dalam penelitian ini bahan hukum sekunde yang digunakan meliputi: buku-buku ilmiah dibidang hukum, makalah-makalah, jurnal ilmiah, artikel ilmiah. 
Bahan hukum tertier,adalah bahan yang memberikan petunjuk maupun penjelasan terhadap bahan hukum primer dan sekunder. bahan hukum tertier yang digunakan meliputi : kamus besar bahasa indonesia, kamus hukum, situs internet.

Teknik pengumpulan data yang digunakan bahan hukum : 1) studi kepustakaan (library research), teknik analisi data dalam artikel ini menggunakan metode deduktif. Metode ini berpangkal dari pengajuan premis mayor kemudian diajukan premis minor atau akan ditarik kesimpulan dari suatu permasalahan yang umum terhadap permaslahan khusus yang dihadapi.

\section{Hasil Penelitian Dan Pembahasan}

1. Gambaran Umum Lembaga Pemasyarakatan Perempuan kelas IIA Yogyakarta

Menurut data Lembaga Pemasyarakatan Kelas IIA Yogyakarta, bangunan peninggalan Kolonial Belanda itu dahulu bernama Gevangenis En Huis Van Bewaring, berganti Pendjara Djogjakarta, kemudian Kependjaraan Daerah Istimewa Djogjakarta hingga kini Lapas Kelas IIA Yogyakarta.

Letaknya di Jalan Tamansiswa Nomor 6 Yogyakarta, diperkirakan dibangun pada 1910 hingga 1915, Selain penjara Yogyakarta, penjara pusat lain yang dibangun Belanda berada di Jakarta, Surabaya, Surakarta, Padang dan Makasar. Lapas itu memiliki luas tanah $24.300 \mathrm{~m}^{2}$ dan luas bangunan $8553 \mathrm{~m}^{2}$, terdiri dari tiga bagian bangunan utama yaitu kantor petugas, enam blok sel untuk pria dan satu blok sel untuk wanita. Lapas mempunyai kapasitas daya tampung sebanyak 800 orang.Di dalam area lapas terdapat Rumah Sakit Lapas Yogyakarta yang terdiri dari 3 kamar.Ada pula fasilitas lain seperti dapur, gedung aula, masjid, gereja, dan gedung bimbingan kerja (bimker).

Lapas yang dahulu juga disebut Gevangenis Laan Wirogunan itu dibangun awalnya untuk menghukum orang-orang pribumi yang melakukan kesalahan saat Belanda masih berkuasa, sebab sebelumnya hukuman kurungan tak berlaku bagi warga Indonesia kala itu. Disebut dalam situs kebudayaan.kemdikbud.go.id, sejarah kepenjaraan di Hindia Belanda dimulai tahun 1872 dengan berlakunya Wetboek van Strafrecht voor de Inlanders in Nederlandsch Indie (Kitab Undang- 
undang Hukum Pidana untuk orang-orang pribumi di Hindia Belanda).

Sebelum tahun 1872 peraturan yang dilakukan untuk orang hukuman adalah di sesuaikan dengan peraturan adat-istiadat daerah setempat, tidak ada hukuman penjara atau kurungan bagi orang Indonesia. Orang Indonesia kala itu dihukum dengan hukuman kerja, hukuman mati dan denda.Orang hukuman ditampung dalam Gestraften Kuartier untuk kemudian pada pagi harinya digiring ke tempattempat pekerjaan yang berada diluar tembok penampung. Keadaan orang hukuman pada saat itu sangat menyedihkan.Kekurangan makanan namun harus bekerja keras.Akibat penderitaan yang berat tersebut, maka banyak para napi yang melarikan diri.

Pada tahun 1905 muncul kebijakan (policy) baru bagi orang-orang hukuman. Orang-orang hukuman mulai dipekerjakan didalam lingkungan tembok penampung, akibat banyak kasus pelarian diri orang hukuman tersebut.Untuk keperluan policy baru ini, tempat-tempat penampungan yang sudah didirikan yaitu di Batavia, Surabaya, Surakarta, Yogyakarta, Padang dan Makasar diubah menjadi penjara-penjara pusat.

Lapas Wirogunan di Yogyakarta adalah satu penjara pusat yang dibangun pemerintah kolonial Belanda dalam rangka menampung orang hukuman pada masa lalu. Adapun bangunan- bangunan yang dibangun berfungsi sebagai barakbarak kerja yang diperuntukkan bagi para tahanan. Orang-orang hukuman yang ada dikenakan hukuman kerja seperti penyamakan kulit, pembuatan sepatu maupun kerja paksa lainnya.

Berdasarkan penjelasan Bapak Ambar selaku staff kepegawaian Lapas Kelas IIA Yogyakaerta dan sebagai pendamping mahasiswa yang sedang melaksanakan penelitian di Lapas tersebut. Awal mulanya di Yogyakarta belum ada LP Perempuan, pada kenyataanya ada WBP Tahanan/narapidana wanita di Yogyakarta.Narapidana wanita berbeda dengan narapidana pria, karena narapidana wanita mempunyai keistimewaan yang tentu tidak dimiliki oleh narapidana pria, seperti siklus menstruasi, hamil, melahirkan, menyusui. Sehingga Ka Kanwil Kemenkumham DIY mempunyai kebijkan menghimpun atau mengumpulkan semua WBP Tahanan/Napi perempuan untuk ditempatkan pada 1 
(satu) institusi.

Dalam hal ini Lapas IIA Yogyakarta pada tahun 2013 ditunjuk sbagai institusi yang menampung WBP Tahanan/ Narapidana perempuan seluruh DIY. Darisitu bisa diketahui jumlah WBP Perempuan cukup banyak, ini sebagai dasar Ka Kanwil Kemenkumham mengajukan usulan dibentuknya Lapas Perempuan ke Kementerian Hukum dan HAM melalui Direktorat Jenderal Pemasyarakatan.

Berdasarkan narasumber salah satu staff kepegawaian diperoleh informasi bahwa seiring berjalannya waktu WBP Perempuan semakin banyak lebih dari 100 orang sehingga pada tanggal 20 Desember 2016 Dilantik Kepala Lembaga Pemasyarakatan Perempuan Kelas IIB Yogyakarta. Segala Fasilitas sarana dan Prasarana WBP Perempuan masih menginduk pada Lapas Kelas IIA Yogyakarta seperti, pembinaan kepribadian masih di dampingi oleh petugas Lapas Kelas IIA Yogyakarta contohnya kegiatan gereja, pelayanan kesehatan dan pelayanan makanan 100\% masih ditangani oleh petugas Lapas Kelas IIA Yogyakarta, namun pembinaan kemandirian sudah bisa dilaksanakan secara mandiri oleh petugas Lapas Perempuan Kelas IIB Yogyakarta, contohnya menjahit, senitari, menyulam, batik, merajut tas, hadrah.

Adanya model pembinaan bagi narapidana di dalam Lembaga Pemasyarakatan Perempuan Kelas IIB Yogyakarta tidak terlepas dari sebuah dinamika, yang bertujuan untuk lebih banyak memberikan bekal bagi Narapidana dalam menyongsong kehidupan setelah selesai menjalani masa hukuman (bebas). Pemasyarakatan dinyatakan sebagai suatu sistem pembinaan terhadap para pelanggar hukum dan sebagai pengejawantahan keadilan yang bertujuan untuk mencapai reintegrasi sosial atau pulihnya kesatuan hubungan antara warga binaan Pemmasyarakatan dengan masyarakat.untuk mencapai tujuan sesuai yang diharapkan Lembaga Pemasyarakatan Perempuan Kelas IIB Yogyakarta mempunyai suatu Visi dan Misi yang berbunyi,

\section{VISI}

Mengedepankan Lembaga Pemasyarakatan yang bersih, kondusif, tertib dan transparan dengan dukungan petugas yang berintegritas dan berkompeten dalam pembinaan WBP. 


\section{MISI}

1) Mewujudkan tertib pelaksanaan tupoksi Pemasyarakatan secara konsisten dengan mengedepankan penghormatan terhadap hukum dan HAM serta transparansi publik.

2) Membangun kerja sama dengan mengoptimalkan keterlibatan stake holder dan masyarakat dalam upaya pembinaan WBP.

3) Mendayagunakan potensi sumber daya manusia petugas dengan kemampuan penguasaan tugas yang tinggi dan inovatif serta berakhlak mulia.

\section{Pelaksanaan Pemenuhan Hak Atas Pelayanan Kesehatan Bagi Narapidana} Perempuan Dalam Keadaan Hamil di Lembaga Pemasyarakatan Perempuan

\section{Kelas IIB Yogyakarta}

Kesehatan adalah sebagai salah satu unsur kesejahteraan umum yang harus diwujudkan sesuai dengan cita-cita bangsa indonesia. Pembangunan kesehatan harus memperhatikan betbagai asas yang memberikan arah pembangunan kesehatan dan dilaksanakan mellaui upaya kesehatan seperti asas perikemanusiaan yang berdasarkan ketuhanan Yang aha Esa; asas manfaat; asas usaha bersama dan kekeluargaan; asas adil dan merata; asas perikehidupan dalam keseimbangan; asas kepercayaan pada kemampuan dan kekuatan sendiri.

Kesehatan adalah HAM dan salah satu unsur yang harus diwujudkan sesuai dengan cita-cita bangsa indonesia sebagaimana tercantum dalam pancasila dan UUD Tahun 1945, demikian landasan filosofis yang terkandung dalam undangundang Nomor 36 Tahun 2009 tentang Kesehatan. Menurut pasal 1 angka 1 pengertiann kesehatan adalah keadaan sehat, baik secara fisik, mental, spiritual maupun sosial yang hidup produktif memungkinkan setiap orang untuk hidup produktif secara sosial dan ekonomis. Kesehatan disini juga termmasuk kesehtan reproduksi. Berdasarkan Plan of Action hasil International Conference on Population and Development (ICPD) 1994 yang telah ditandatangani oleh pemeritah Indonesia pada tahun1994, kesehatan reproduksi adalah bagian integral dari HAM. Kesehatan reproduksi didefinisikan sebagai keadaan sehat sejahtera 
secara fisik, mental dan sosial secara utuh, tiidak hanya terbebas dari penyakit dan kecacatan dalam segala hal yang terkait dengan sistem reproduksi dan fungsi serta proses reproduksi.

Kesehatan mempunyai peranan besar dalam meningkatkan derjat hidup masyarakat, maka semua negara berupaya menyelenggarakan pelayanan kesehatan yang sebaik-baiknya. Pelayanan kesehatan ini berarti setiap upaya yang diselenggarakan sendiri atau bersama-sama dalam suatu organisasi untuk memelihara dan meningkatkan kesehatan, mencegah dan mengobati penyakit, serta memulihhkan kesehatan perseorangan kelompok ataupun masyarakat (Wiku, 2008: 5).

Hak atas Kesehatan mrupakan hak konstitusional masyarakat ini diatur dalam UUD tahun 1945 pasal 28 huruf $\mathrm{H}$ ayat (1) dan pasal 34 ayat (3) yaitu bahwa setiap orang berhak hidup sejahtera lahir dan batin, bertempat tinggal, dan mendapatkan lingkungan hidup yang baik dan sehat berhak memperoleh pelayanan kesehatan dan fasilitas pelayanan umum yang layak.

Sistem pemasyarakatan merupakan bagian dari sistem peradilan pidana di indonesia dimana sistem ini mempunyai karakteristik lain dibandingkan dengan sistem penegak huum lainnya, seperti penyidikan (kepolisisan), penuntutan (kejaksaan), pemutusan (pengadilan). Karena tujuan dari sistem pemasyarakatan ini adalah bekas narapidana tidak akan melanggar hukum. Sedangkan dalam sistem ini narapidana wanita mempunyai hak khusus.

Struktur hukum atau pranata hukum dalam Teori lawrence meir Friedman ini disebut sebagai sistem struktural yang menentuan bisa atau tidaknya hukum itu dilaksanakan dengan baik. Struktur hukum berdasarkan UU No.8 Tahun 1981 meliputi : mulai dari kepolisian, kejaksaan, pengadilan dan badan pelaksana pidana (LAPAS). Kewenangan lembaga penegak hukum dijamin oleh undangundang. Sehingga dalam melaksanakan tugas dan tanggungjawab terlepas dari pengaruh kekuasaan pemerintah dan pengaruh lain. Terdapat adagium yang menyatakan "fiat justitia et pereat mundus" (meskipun dunia ini runtuh hukum harus ditegakkan). Hukum tidak dapat berjalan atau tegak bila tidak ada aparat penegak hukum yang kredibilitas, kompeten dan independen. Seberapa bagusnya 
suatu peraturan perundang-undangan bila tidak didukung dengan aparat penegak hukum yang baik maka keadilan hanya angan-angan.

Dalam hal ini sistem pelaksanaan narapidana wanita di Lembaga Pemasyarakatan Perempuan Kelas IIB Yogyakarta ditinjau dari Hak Asasi Manusia. Karena HAM sudah menjadi kodrati dalam diri manusia. Sistem pelaksanaan yang ada dilapangan sama halnya dengan yang lain harus sesuai dengan perundang-undangan, disini peneliti melihat ada keseimbangan antara narapidana wanita dan narapidana laki-laki, hal ini berdasarkan pada badan internasional yaitu PBB pada tahun 1957 mengeluarkan "Standart minimum rules for the treatment of prisoners" yang artinya setiap narapidana saat menjalani hukuman harus dipenuhi syarat dan hak-haknya, seperti buku regristrasi, pemisahan narapidana pria dan wanita,dewasa dan anak-anak, fasilitas akomodasi yang memadai,pakaina ,temat tidur,makanan sehat, hak olahraga, hak mendapatkan pelayanan dokter atau hak kesehatan.

Dalam standart minimum PBB, peneliti menemukan fakta di lapangan, narapidan wanita sudah memiliki pemisahan sendiri dengan tepat narapidana lakilaki, meskipun LAPAS masih dalam satu bangunan, sehingga hal ini akan membantu terpenuhinya hak-hak narapidana perempuan. Menurut peneliti hal ini sesuai dengan undang-undang No 12 tahun 1995 tentang pemasyarakatan pasal 1 dan 2 yaitu :

Ayat (1) : "Dalam rangka pembinaan terhadap narapidana di LAPAS di lakukan penggolongan atas dasar : a)umur, b)jenis kelamin, c)lama pidana yang dijatuhkan, d)jenis kejahatan, e)kriteria lainnya sesuai dengan kebutuhan perkembangan pembinaan."

Ayat (2) : "Pembinaan narapidna wanita di laksanakan di LAPAS wanita."

Ini jelas sudah sesuai dengan undang-undang yang dimaksud yaitu undangundang No 12 tahun 1995 tentang pemasyarakatan ayat 1 dan 2 yang sudah dijalankan.

Mengenai pemenuhan hak memperoleh pelayanan kesehatan bagi narapidana wanita yang sedang hamil di Lembaga Pemasyarakatan PerempuanKelas IIB Yogyakarta, karena kesehatan merupakan hak dasar semua 
warga negara hal ini secara jelas dinyatakan dalam pasal 28H ayat (1) UUD Tahun 1945. Terkait dengan hak reproduksi perempuan yang merupakan hak khusus dikarenakan fungsi reproduksinya, yang tidak dimiliki laki-laki. Pasal $28 \mathrm{H}$ ayat (2) menyebutkan bahwa "setiap orang mendapat kemudahan dan perlaukan khusus untuk memperoleh kesempatan dan manfaat yang sama guna mencapai persamaan dan keadilan".

Selanjutnya, ketentuan mengenai hak reproduksi diatur dalam pasl 49 ayat (2) Undang-Undang Nomor 39 Tahun 1999 tentang Hak Asasi Manusia (UU HAM) menyatakan bahwa "perempuan berhak untuk mendapatkan perlindungan khusus dalam pelaksanaan pekerjaan atau profesinya terhadap hal-hal yang dapat mengancam keselamatan dan atau kesehatannya berkenaan dengan fungsi reproduksi perempuan". Penjelasan ayat (2) menyebutka bahwa aspek perlindungan khusus tersebut pada dua hal yakni pelayanan kesehatan yang berkaitan dengan haid, hamil, melahirkan, dan pemberian kesempatan untuk menyusui anak.

Berhubungan dengan pemenuhan hak kesehatan reproduksi narapidanan perempuan di Lapas Perempuan Kelas IIB Yogyakarta, berdasarkan hasil penelitian terdapat narapidana yang melahirkan bayinya, namun bayi tersebut diajak bersama dalam satu sel dengan ibunya dan narapidanaa lainnya. Ketiadaan ruangan menyebabkan sang bayi harus tinggal berbarengan dengan penghuni lainnya. Hal tersebut dapat berpengaruh kepada kesehatan bayi yang masih sangat rentan terhadap penyakit serta psikologisnya. Di Lapas perempuan Kelas IIB Yogyakarta memang belum tersedia ruangan khusus untuk narapidana/tahanan yang sedang hamil, melahirkan, dan menyusui.

Dalam pasal 20 ayat (1) Peraturan Pemerintah Nomor 32 Tahun 1999 tentang syarat dan tata cara Pelaksanaan Hak Warga Binaan dinyatakan bahwa narapidana dan anak didik pemasyarakatan yang sakit, hamil, atau menyusui berhak mendapatkan makann tambahan sesuai dengan petunjuk dokter. Dalam penjelasan pasal tersebut dinyatakan bahwa yang dimaksud dengan makanan tambahan adalah penambahan jumlah kalori di atas rata-rata jumlah kalori yang ditetapkan. Bagi wanita yang sedang hamil ditambah 300 (tiga ratus) kalori 
seorang sehari. Bagi wanita yang sedang menysui dapat ditambah antara 800 (delapan ratus) sampai dengan 1000 (seribu) kalori seorang sehari. Dalam pemberian makanan tambahan terhadap ibu dan bayi memang dilakukan di lapas. Bagi ibu yang sedang hamil dan menyusui diberikan susu serta makanan tambahn berupa bubur kacang hijau. Tambahan vitamin diberikan oleh dokter yang ada di Lapas. Untuk narapidana perempuan yang melahirkan dibawa ke rumah sakit, karena di Lapas tidak terdapat bidan dan ibu melahirkan memiliki resiko lebih tinggi.

Di dalam Lapas terdapat narapidana yang sedang hamil dan satu sel dengan penghuni lainnya. Narapidana yang hamil ini memiliki hak yang sama dengan lainnya nnamun lebih diperhatikan dengan diberikan susu ibu hamil dan makanan tambahan lainnya seperti bubur kacang hijau ataupun buah. Narapidana ini sering datang ke poliklinik utuk konsultasi ataupun memeriksakan kehamilannnya. 
Tabel 4.1

Standar Kecukupan Gizi yang Dianjurkan

(Berdasarkan Widyakarya Pangan dan Gizi Tahun 2004)

\begin{tabular}{|c|c|c|c|c|}
\hline \multirow[t]{2}{*}{ No } & \multirow{2}{*}{$\begin{array}{c}\text { Macam } \\
\text { Konsumen }\end{array}$} & \multicolumn{3}{|c|}{ Widyakarya Pangan dan Gizi 2004} \\
\hline & & Golongan Usia & Energi (Kalori) & Protein \\
\hline \multirow[t]{4}{*}{1} & \multirow[t]{4}{*}{ Pria } & $13-15$ th & 2400 & 60 \\
\hline & & $16-19$ th & 2500 & 65 \\
\hline & & $20-45$ th & 2800 & 60 \\
\hline & & $46-59$ th & 2500 & 60 \\
\hline \multirow[t]{4}{*}{2} & \multirow[t]{4}{*}{ Wanita } & $13-15$ th & 2100 & 57 \\
\hline & & $16-19$ th & 2000 & 50 \\
\hline & & $20-45$ th & 2200 & 50 \\
\hline & & $46-59$ th & 2100 & 50 \\
\hline
\end{tabular}

Sumber: Pedoman Penyelenggaraan Makanan di Lembaga Pemasyarakatan dan Rumah Tahanan Negara, Departemen Kesehatan RI, Direktorat Jenderal Bina Kesehatan Masyarakat, Direktorat Bina Gizi Masyarakat, 2009

Dari tabel diatas terlihat bahwa pemenuhan gizi dan makanan kepada warga binaan/tahanan harus berpedoman pada penyelenggaraan makanan dari lembaga pemasyarakatan dan rumah tahanan negara, Departemen Kesehatan RI, Direktorat Jenderal Bina Kesehatan Masyarakat, Direktorat Bina Gizi Masyarakat 2009. Makanan dengan gizi seimbang dibutuhkan oleh warga binaan pemasyarakatan khusunya narapidana yang sedang hamil untuk mempertahankan dan meningkatkan derajat kesehatan agar tidak sakit dan dapat melakukan aktivitas sehari-hari dan pastinya agar pertumbuhan dan perkembangan janin baik dan sehat.pemenuhan gizi yang baik kepada warga binaan ini juga sesuai dengan aturan 20 SMR yang menyatakan bahwa setiap orang yang dipenjarakan harus diberi oleh pengelola penjara pada jam-jam biasa makanan yang bergizi cukup untuk kesehatan dan kekuatan, bermutu menyehatkan dan disipkan dan disuguhkan dengan baik.

Selain monitoring ada juga evaluasi yang bertujuan untuk menilai 
pelaksanaan kegiatan pelayanan kesehatan bagi narapidana wanita yang sedang hamil sesuai dengan rencana dan kebijakan yang telah disusun sehingga dapat mencapai sasaran yang dikehendaki.Evaluasi dilakukan pada narapidana wanita, Petugas Pelaksana, dan Pengelola di Lembaga Pemasyarakatan Perempuan Kelas IIB Yogyakarta.

Adanya monitoring dan evaluasi dari dokter, Kepala Keamanan, Kasie Binadik, dan Kepala LAPAS Kelas IIA Yogyakarta dalam setiap penyelenggaraan makanan guna menunjang kesehatan narapidana wanita termasuk narapidana wanita yang sedang hamil di Lembaga Pemasyarakatan Perempuan Kelas IIB Yogyakrta maka dapat meminimalisir segala hambatan yang terjadi. Evaluasi dan monitoring ini tidak hanya dilakukan pada penyelenggaraan saja, namun dilakukan disetiap kegiatan pembinaan di dalam Lembaga Pemasyarakatan Perempuan Kelas IIB Yogyakarta. Sedangkan dalam pemenuhan pelayanan kesehatan bagi narapidana wanita terutama narapidana wanita yang sedang hamil ini dapat terselenggara dengan baik karena adanya ketanggapan, kesiagaan, kecekatan para petugas pemasyarakatan yang bertugas. Selain itu penanganan yang baik diperlukan biaya yang banyak. Biaya yang biasanya menjadi proses penghambat dalam upaya pemenuhan pelayanan kesehatan tidak terjadi pada Lembaga Pemasyarakatan Perempuan Kelas IIB Yogyakarta karena semua biaya telah di cover sepenuhnya oleh pemerintah dalam bentuk JAMKESMAS yang kini menjadi BPJS.

\section{Simpulan}

Setiap narapidana wanita yang sedang hamil dipenuhi haknya untuk memperoleh pelayanan kesehatan di Lembaga Pemasyarkatan Perempuan Kelas IIB Yogyakarta. Upaya pelaksanaan pemenuhan atas pelayanan kesehatan ini tak luput dari semua kebutuhan yang mendasar untuk narapidana wanita yang sedang hamil termasuk upaya perbaikan gizi ibu hamil dalam tercakup dalam makanan yang diberikan setiap hari. Setiap narapidana wanita yang sedang hamil diberikan makanan 3 kali sehari. Selain itu, bagi narapidana wanita yang sedang hamil di Lembaga Pemasyarakatan Perempuan Kelas IIB Yogyakarta diberikan makanan 
tambahan berupa bubur kacang ijo atau buah yang bervitamin seperti pisang yang diberikan setiap 2 hari sehari dengan jumlah kalori lebih banyak daripada narapidana wanita yang tidak hamil. Di Lembaga Pemasyarakatan Perempuan Kelas IIB Yogyakarta makanan didisbutribusikan dibantu oleh tamping dapur secara baik yang layak diperuntukkan nasi, sayur, lauk-pauk, dan buah. Lembaga Pemasyarakatan Perempuan Kelas IIB Yogyakarta sangat memperhatikan kesehatan narapidana perempuan termasuk narapidana perempuan yang sedang hamil dilakukan kunjungan anternatal care ke puskesmas secara rutin pada trimester 1-2 sebanyak satu bulan sekali sedangkan pada trimester3 dilakukan lebih intensif sebanyak 2 minggu sekali. Kunjungan anternatal care ini seperti pemeriksaan tekanan darah ibu, penghitungan detak jantung janin dengan alat Doppler, dan pemberian vitamin untuk ibu secara rutin.

Selama ini tidak ada hal-hal yang menghambat pelaksanaan pemenuhan hak atas pelayanan kesehatan bagi narapidana wanita yang sedang hamil di Lembaga Pemasyarakatan Perempuan Kelas IIB Yogyakarta, karena selalu ada monitoring dan evaluasi yang dilakukan oleh Kepala Lembaga Pemasyarakatan Perempuan Kelas IIB Yogyakarta, Kantor Wilayah Kemenkumham DIY secara rutin pada setiap kegiatan pembinaan di Lembaga Pemasyarakatan Perempuan KelasIIB Yogyakarta. Selain itu kecekatan, ketanggapan dan kepekaan para petugas Pemasyarakatan di Lembaga Pemasyarakatan Perempuan KelasIIB Yogyakarta ini membuat narapidana wanita yang sedang hamil merasa nyaman dan tenang meskipun mereka dalam kondisi hamil, sehingga meminimalisir segala hambatan yang terjadi dalam pemenuhan hak memperoleh pelayanan kesehatan di Lembaga Pemasyarakatan Perempuan Kelas IIB Yogyakarta.

\section{E. Saran}

Kepada pihak Lembaga Pemasyarakatan Perempuan Kelas IIB Yogyakarta hendaknya lebih meningkatkan pada kegiatan-kegiatan yang bermanfaat seperti keterampilan, olahraga dan lain sebagainya, khususnya yang berkaitan dengan narapidana perempuan yang sedang hamil di Lapas, yaitu sosialisasi untuk senam hamil ataupun kelas ibu hamil, Karena kegiatan inilah yang akan lebih positif bagi 
mereka agar terjaminnya hak-hak narapidana wanita.

Untuk di wilayah DIY sebaiknya pemerintah mendirikan LAPAS khusus perempuan beserta sarana prasarana tanpa menginduk di Lapas kelas IIA Yogyakarta sehingga lebih mandiri dan pemenuhan hak untuk narapidana perempuan akan lebih terjamin dan terpunuhi.

\section{F. Daftar Pustaka}

Adi Sujatno. 2004. Sistem Pemasyarakatan Indonesia (Membangun Manusia Mandiri),Jakarta: Direktorat Jenderal Pemasyarakatan Departemen Kehakiman dan HAM RI.

Adi Sujatno. 2001.Negara Tanpa Penjara (Sebuah Renungan), Jakarta: Montas Ad.

Austin Fagothey. 1972, Rights and Reason, Ethics in Theory and Practice, (Saint Louis: The CV Mosby Company,).

Dwidja Priyatno. 2006. Sistem Pelaksanaan Pidana Penjara Di Indonesia. Cetakan I. Bandung : PT. Refika Aditama

Dikutip oleh Wolfgang Friedman. 2000. Legal Theory. London: Stevens \& Sons, 1953, dikutip oleh Satjipto Rahardjo, Ilmu Hukum. Bandung: Citra Adyta Bhakti.

Heru Susetyo. 2010. "Kedudukan hukum perempuan di indonesia". Jurnal Legislasi Indonesia, Vol. 7 No.2. Agustus. Jakarta; Direktorat Jenderal Peraturan Perundangan-Undangan Kementerian Hukum dan Hak Asasi Manusia RI

Isharyanto. 2016. Hukum Pelayanan Kesehatan.Jakarta: Herya Media.

James W. Nickel. 1996. Hak Asasi Manusia: Refleksi Filosofis atas Deklarasi Universal Hak Asasi Manusia. Jakarta: PT Gramedia Pustaka Utama.

Jimmly Asshiddiqie. 2005. Hukum Tata Negara dan Pilar-Pilar Demokrasi. Jakarta: Konstitusi Press.

Koentjoro Poerbopranoto.1975. Beberapa Catatan Hukum Tata Pemerintahan dan Peradilan Administrasi Negara.(Bandung: Alumni). mengutip Hutink, Arresten Over Burgerlijk Recht. dan juga dari Van Der Pot, Nederlandsche Bestuursrecht. 
Matthew J.Gibney. 2003, Introduction to Globalizing Rights, dalam Matthew J. Gibney (ed), Globalizing Rigths, (Oxford University Press).

Muladi. 1996. Hukum dan Hak Asasi Manusia, dalam Buku Kedaulatan Rakyat, Hak Asasi Manusia dan Negara Hukum. Jakarta: Gaya Media Pratama.

Peter Mahmud Marzuki. 2014. Penelitian Hukum. Jakarta: Penerbit Prenada Media Group.

Pusat Studi Hak Asasi Manusia Universitas Islam Indonesia. 2006. Hukum Hak Asasi Manusia (Yogyakarta : Pusat Studi Hak Asasi Manusia Universitas Islam Indonesia)

Ruggie Jihn Gerad. 1983.Human Rights and The Future International Community, (Deadalus).

Saafroedin Bahar. 1999. Hak Asasi Manusia. Jakarta: Pustaka Sinar Harapan.

SatjiptoRahardjo. 2000. IlmuHukum. Bandung: Citra Adyta Bhakti.

Satya Arinanto. 2008. Hak Asasi Manusia Dalam Transisi Politik di Indonesia. Jakarta: Pusat Studi Hukum Tata Negara, Fakultas Hukum Universitas Indonesia.

Satya Arinanto. 2008. Hukum dan Hak Asasi Manusia. Yogyakarta : PUSHAM UII.

Soerjono Soekanto, dan Sri Mamudji. 2004. Penelitian Hukum Normatif. Cetakan ke-8. Jakarta : PT. Raja Grafindo Persada

Yuliana Primawardani. 2006. "Dampak Diskriminatif Perda No.8 Seri E Tahun 2005 tentang Pelarangan Pelacuran terhadap Hak Perempuan” dalam Jurnal HAM Vol. 3. No.1. April. Jakarta: Badan Penelitiandan Pengembangan Hukum dan HAM Departemen Hukum dan Hak Asasi Manusia R.I. 